\title{
CHROMATOGRAPHIC PARAMETERS AS TOOLS FOR PREDICTING THE BIOLOGICAL ACTIVITY OF AZO DERIVATIVES
}

\author{
Suzana Apostolov*, Gyöngyi Vastag \\ University of Novi Sad, Faculty of Sciences, Department of Chemistry, \\ Biochemistry and Environmental Protection, Trg Dositeja Obradovića 3, 21000 Novi Sad, Serbia \\ suzana.apostolov@dh.uns.ac.rs
}

\begin{abstract}
Preliminary assessment of the bioactive profile of azo derivatives was performed by applying drug-likeness rules. As the presumed criteria of lipophilicity, chromatographic parameters $\left(R_{\mathrm{M}}{ }^{0}, m\right.$ and $C_{0}$ ) were calculated in mixtures of water/methanol and water/acetonitrile by using reversed phase thinlayer chromatography (RPTLC C18/UV254s). The relationships between chromatographic parameters and relevant software parameters for the biological activity of azo derivatives were examined by linear regression and by two multivariate methods. Good linear relationships were obtained for each applied system. The multivariate methods show the similarity of chromatographic parameters $\left(R_{\mathrm{M}}{ }^{0}, C_{0}\right)$ with standard measures of the lipophilicity and pharmacokinetic predictors. The chromatographic parameter $m$ obtained in the same conditions exhibits better agreement with the drug-likeness and toxicity parameters. The polarity of the substituent was found to have a higher impact on the values of azo derivatives' bioactivity parameters than its electronic effects.
\end{abstract}

Keywords: chromatographic parameters; drug-likeness rules; biological activity parameters; multivariate methods; azo derivatives

\section{ХРОМАТОГРАФСКИ ПАРАМЕТРИ КАКО АЛАТКИ ЗА ПРЕДВИДУВАЊЕ НА БИОЛОШКАТА АКТИВНОСТ НА АЗОДЕРИВАТИ}

\begin{abstract}
Извршена е прелиминарна процена на биоактивниот профил на азодеривати со примена на правила за „сличност со лек“. Како претпоставените критериуми за липофилност се пресметани, хроматографските параметри $\left(R_{\mathrm{M}}{ }^{0}, m\right.$ и $\left.C_{0}\right)$ во смеси вода/метанол и вода/ацетонитрил со примена на реверзнофазна тенкослојна хроматографија (RPTLC C18/UV254s). Зависноста помеѓу хроматографските параметри и релевантните софтверски параметри на биолошката активност на азодериватите е проверена со линеарна регресија и со две мултиваријабилни методи. Добиени се добри линеарни зависности за секој применет систем. Мултиваријабилните методи ја покажуваат сличноста на хроматографските параметри $\left(R_{\mathrm{M}}{ }^{0}, C_{0}\right)$ со стандардните мерила на липофилност и на фармакокинетички параметри. Хроматографскиот параметар $m$ добиен при исти услови покажува подобро совпаѓање со параметрите на сличност со лекот и за токсичност. Утврдено е дека поларитетот на супституентот има поголемо влијание врз вредноста на биоактивните параметри на азодериватите одошто врз нивните електронски ефекти.
\end{abstract}

Клучни зборови: хроматографски параметри; правила на „сличност со лек“; биолошки параметри на активност; мултиваријабилни методи; азодеривати

\section{INTRODUCTION}

The need for stable, resistant and intense colors has led to an increase in the production and consumption of the synthetic dyes. This has resulted in approximately 100,000 different types of dyes being used in the textile industry today [1]. Azo dyes are the most versatile and the most wide- 
spread group used for coloring fabrics. In addition to the desired stability, they also show an extremely difficult degradability, which negatively affects aquatic ecosystems $[2,3]$. The cleavage products of azo dyes show toxic, mutagenic, carcinogenic and teratogenic effects [4-7]. Also, it is known that azo derivatives and their metal complexes exhibit potent anti-inflammatory, antitumor and antimicrobial activity [8-10].

Conducting the preliminary conclusions regarding the activity, physico-chemical properties or retention behavior of azo derivatives based on their structures is possible by developing various mathematical models [11-13]. Selection of appropriate molecular descriptors for forming a meaningful mathematical model is a precondition to rationalizing the production of new azo dyes which would be in line with market, environmental and legal requirements [14]. In silico studies of the new potentially bioactive compounds usually include checking drug-likeness rules (the Lipinski's rule of five (Ro5), the Ghose's rule (GR) and the Veber's rule (VR)) as well as getting information about the compound's lipophilicity, a crucial molecular descriptor associated with its bioavailability, pharmacokinetics and toxicity [15-19]. Lipophilicity is usually defined by the partition coefficient, $\log P$, but it is increasingly expressed by the parameters obtained by reversed phase thin-layer chromatography [20-22].

The existence, intensity and rate of biological activity of a compound are conditioned by a number of its pharmacokinetic properties. Among them, permeability primarily affects a compound's bioavailability, intestinal absorption, passage through the blood-brain barrier, efficacy or toxicity, and elimination through the kidneys and liver [23-25]. Also, information about the percent of plasma protein binding, $P P B$, is necessary since only the free concentration of the bioactive compound in tissues guarantees its biological effect [26].

Given that azo derivatives are invasive compounds, predicting the health risks for consumers exposed to them should include assessing a dye's ability to penetrate the skin barrier through the stratum corneum and through the ocular tissues $[27,28]$. Predicting the harmful effects of the synthetic dyes should cover various aspects of toxicity, among which particular attention is paid to cardiac toxicity testing [29]. Since the aquatic ecosystems are often exposed to azo dyes, early research also includes predicting their ecotoxicity [30].

The aim of this study was an in silico estimation of the biological activity of selected azo derivatives. In the first phase, their compliance with the drug-likeness rules was checked. Alternative measures of lipophilicity for selected azo compounds were determined by using reversed phase thin-layer chromatography, RPTLC C18/UV254s, in the presence of two organic modifiers (methanol and acetonitrile). Also, their pharmacokinetic properties and toxicological profiles were evaluated. Correlation of the bioactivity parameters of the tested azo derivatives was examined by applying linear regression and two multivariate methods (Cluster analysis and Principal component analysis). High-quality mathematical models were obtained as confirmed by statistical parameters.

\section{EXPERIMENTAL}

\subsection{Chromatographic measurements}

Thin-layer chromatography was performed on $5 \mathrm{~cm} \times 10 \mathrm{~cm}$ commercial plates (RP$18 \mathrm{~W} / \mathrm{UV}_{254}$ Macherey-Nagel GmBH and Co., Duren, Germany). As a mobile phase, mixtures of LC grade organic modifiers (methanol and acetonitrile, J. T. Baker, Deventer, the Netherlands) with filtered bi-distilled water were used. The content of the organic modifier, $\varphi$, in the mobile phase ranged from $36 \%$ to $52 \%(\mathrm{v} / \mathrm{v})$ in $5 \%$ increments. Solutions of the azo dyes (Table 1) were prepared with ethanol, p.a., (J. T. Baker, Deventer, the Netherlands) in the concentration of $2 \mathrm{mg} \mathrm{ml}^{-1}$. Their synthesis and characterization are described in the literature [31].

\section{Table 1}

Structures of the investigated azo derivatives

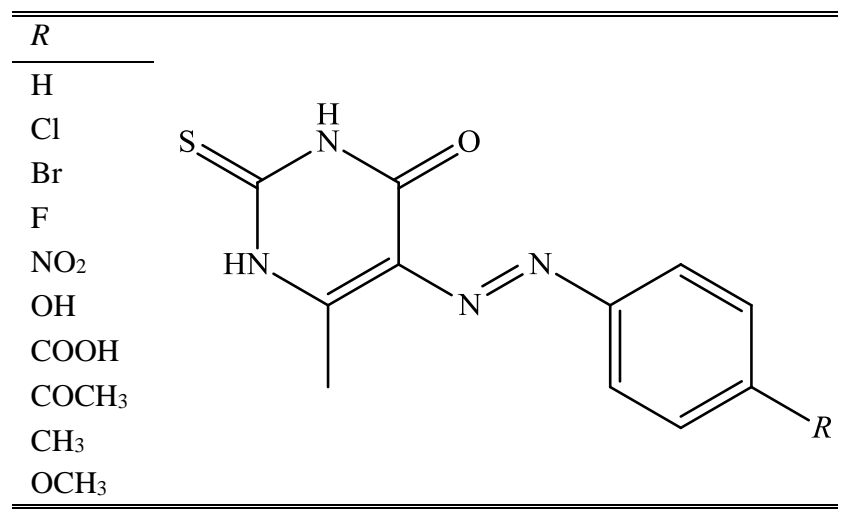

The freshly prepared solutions of each derivative $(0.2 \mu \mathrm{l})$ were spotted on the plates and developed by the ascending technique in saturated chambers at a temperature of $25^{\circ} \mathrm{C}$ with previously prepared aqueous solutions of each organic 
modifier. The front of solvent was approximately 5 $\mathrm{cm}$, the chromatograms were developed for about 20 minutes, and after that the plates were dried in a stream of air. The examined compounds were detected under UV light at $\lambda=254 \mathrm{~nm}$. For each solute-organic modifier combination, three chromatograms were developed, and the average $R_{\mathrm{f}}$ values were calculated.

The $R_{\mathrm{M}}$ values, characterizing the retention in TLC, were calculated according to the BateSmith and Westall equation [32]:

$$
R_{\mathrm{M}}=\log \left(\frac{1}{R_{\mathrm{f}}}-1\right)
$$

Linear correlations between the $R_{\mathrm{M}}$ values of the compounds and the concentration of organic modifier in the mobile phases $(\varphi)$ were calculated with the Soczewiński-Wachtmeister's equation [33]:

$$
R_{\mathrm{M}}=R_{\mathrm{M}}^{0}+m \varphi
$$

where the intercept $R_{\mathrm{M}}{ }^{0}$ (chromatographic retention constant) represents an $R_{\mathrm{M}}$ value extrapolated to $0 \% \mathrm{v} / \mathrm{v}$ of organic modifier/water mobile phase system. The slope of the regression plot, $m$, is related to the specific hydrophobic surface area of the compound [34]. In addition to $R_{\mathrm{M}}{ }^{0}$, parameter $m$ can be regarded as an alternative measure of lipophilicity.

Based on the slope and the intercept of the Soczewiński-Wachtmeister's equation, another parameter of lipophilicity, $C_{0}$, can be calculated [35]:

$$
C_{0}=-\frac{R_{\mathrm{M}}^{0}}{m}
$$

Parameter $C_{0}$ corresponds to the concentration of the organic component of the mobile phase for which the distribution of the analyzed substance between the mobile and stationary phase is equal (1:1). This parameter is considered more reliable in QSAR analysis because it also includes both chromatographic lipophilicity, $R_{\mathrm{M}}{ }^{0}$, and the specific hydrophobic surface area of the solute.

\subsection{In silico properties}

The values of the partition coefficient, $\log P$, were calculated using virtual Computational Chemistry Laboratory, VCCLAB [36]. Molecular descriptors, values of pharmacokinetic predictors, and toxicity parameters were obtained using
Molinspiration, SimulationPlus, and PreADMETonline programs [37-39].

\subsection{Chemometric analysis}

The experimental data were processed by Origin 6.1 software. Multivariate methods were performed by Statistica software v.13.5.017 (StatSoft Inc., Tulsa, OK, USA).

Cluster analysis (CA) and Principal component analysis (PCA) are performed on a matrix in which different measures of lipophilicity $\left(R_{\mathrm{M}}{ }^{0}, m\right.$, $C_{0}, \log P$ ), the pharmacokinetic predictors, and the toxicity parameters of examined compounds represented variables (columns) and the azo derivatives were rows. The matrix data were standardized to ensure equal impact of all analyzed parameters. In $\mathrm{CA}$, the Euclidean distance was applied as a measure of diversity, and the clusters were formed by the Ward method. In PCA, the original data matrix was decomposed to a loading vector (including experimentally and software obtained parameters of lipophilicity, drug-likeness descriptors, pharmacokinetic parameters and toxicity parameters), and score vectors (including the examined azo derivatives).

\section{RESULTS AND DISCUSSION}

\subsection{Compatibility of the studied azo derivatives and the drug-likeness rules}

In compliance with Lipinski's rule of five, a potentially biologically active compound should possess the following: molecular weight $\leq 500$; number of hydrogen bond acceptors $\leq 10(2 \cdot 5)$; number of hydrogen bond donors $\leq 5$, and value of the partition coefficient $\log P \leq 5$.

On the other hand, according to the Ghose's rule, the molecular weight should be within 160480 , values of $\log P$ between -0.4 and 5.6, the total number of atoms in molecule within 20-70, and molar refractivity in the range 40-130.

According to Veber's rule, the number of rotatable bonds should be less than 10 , the sum of hydrogen bond donors and hydrogen bond acceptors not over 12, and total polar surface area less than $140 \AA^{2}$. The relevant molecular descriptors of the examined azo derivatives are shown in Table 2 and Table 3.

It is obvious from the data shown in Table 2 and Table 3 that all of the examined azo derivatives fulfill all of the mentioned drug-likeness rules and thereby theoretically could be biologically active. 
T a ble 2

Selected molecular descriptors of the examined azo derivatives

\begin{tabular}{lccccccc}
\hline \hline$R$ & MW & nON & nOHNH & natoms & $\begin{array}{c}\text { MR } \\
\mathrm{cm}^{3} \mathrm{~mol}^{-1}\end{array}$ & nrotb & TPSA \\
\hline $\mathrm{H}$ & 246.295 & 5 & 2 & 27.0 & 70.15 & 2 & 73.381 \\
$\mathrm{Cl}$ & 280.740 & 5 & 2 & 28.0 & 74.75 & 2 & 73.381 \\
$\mathrm{Br}$ & 325.191 & 5 & 2 & 28.0 & 77.84 & 2 & 73.381 \\
$\mathrm{~F}$ & 264.285 & 5 & 2 & 28.0 & 70.55 & 2 & 73.381 \\
$\mathrm{NO}_{2}$ & 291.292 & 8 & 2 & 30.0 & 77.72 & 3 & 119.205 \\
$\mathrm{OH}$ & 262.294 & 6 & 3 & 29.0 & 71.96 & 2 & 93.609 \\
$\mathrm{COOH}$ & 290.304 & 7 & 3 & 31.0 & 76.96 & 3 & 110.680 \\
$\mathrm{COCH}$ & 288.332 & 6 & 2 & 33.0 & 81.39 & 3 & 90.452 \\
$\mathrm{CH}_{3}$ & 260.322 & 5 & 2 & 31.0 & 76.04 & 2 & 73.381 \\
$\mathrm{OCH}_{3}$ & 276.321 & 6 & 2 & 32.0 & 77.40 & 2 & 82.615 \\
\hline \hline
\end{tabular}

MW - molecular weight; nON - number of hydrogen bond acceptors; $\mathrm{nOHNH}$ - number of hydrogen bond donors; natoms - the total number of atoms in molecule;

MR - molar refractivity; nrotb - the number of rotatable bonds; TPSA - total polar surface area

Ta ble 3

Software obtained $\log P$ values of the tested azo derivatives

\begin{tabular}{lcccccccc}
\hline \hline$R$ & AClog $P$ & Alog $P$ & Alog $P s$ & Mlog $P$ & $\operatorname{milog} P$ & kowwin & X $\log P_{2}$ & X $\log P_{3}$ \\
\hline $\mathrm{H}$ & 2.19 & 2.47 & 2.53 & 1.49 & 2.00 & 2.11 & 2.06 & 1.99 \\
$\mathrm{Cl}$ & 2.81 & 3.14 & 3.23 & 1.77 & 2.68 & 2.76 & 2.68 & 2.61 \\
$\mathrm{Br}$ & 2.89 & 3.22 & 3.30 & 1.91 & 2.82 & 3.00 & 2.85 & 2.68 \\
$\mathrm{~F}$ & 2.25 & 2.68 & 2.68 & 1.63 & 2.17 & 2.31 & 2.22 & 2.09 \\
$\mathrm{NO}_{2}$ & 2.20 & 2.37 & 2.58 & 1.31 & 1.96 & 2.51 & 1.95 & 1.82 \\
$\mathrm{OH}$ & 1.89 & 2.21 & 2.30 & 0.72 & 1.53 & 1.63 & 1.65 & 1.63 \\
$\mathrm{COOH}$ & 1.71 & 2.08 & 2.02 & 0.97 & 1.92 & 1.99 & 1.67 & 1.51 \\
$\mathrm{COCH}_{3}$ & 2.12 & 2.21 & 2.42 & 1.19 & 1.90 & 1.79 & 1.90 & 1.67 \\
$\mathrm{CH}_{3}$ & 2.51 & 2.96 & 2.89 & 1.77 & 2.45 & 2.66 & 2.49 & 2.35 \\
$\mathrm{OCH}_{3}$ & 2.09 & 2.46 & 2.62 & 1.00 & 2.06 & 2.19 & 1.97 & 1.96 \\
\hline \hline
\end{tabular}

Also, it is noticeable from Table 3 that different values of the partition coefficient, $\log P$, were obtained for the same compound. This can be explained by the use of different mathematical methods in the software package for calculating $\log P$. Regardless of the calculating method, the highest value of the partition coefficient was obtained for the compound with $\mathrm{Br}$ as a substituent, and the lowest value was obtained for the derivative with the most polar $\mathrm{COOH}$ group.

\subsection{Determination of the alternative measure of lipophilicity of the studied azo derivatives}

The values of the chromatographic parameters $R_{\mathrm{M}}{ }^{0}, m$ and $C_{0}$ of the tested azo compounds are presented in Table 4.
The high values of the regression coefficients, $r$, indicate the validity of the linear $R_{\mathrm{M}^{-}} \varphi$ dependencies in the chosen field of experimental work.

Bearing in mind that the chromatographic parameter $R_{\mathrm{M}}{ }^{0}$ depends solely on the nature of the compound and not on the solvent used, it was expected that the values would be similar. Despite this, it is noticeable that slightly higher values of the chromatographic parameter $R_{\mathrm{M}}{ }^{0}$ were obtained in methanol. This phenomenon can be explained by the fact that methanol, as a protic and very polar solvent, forms an association with water. In this way, the effect of the organic modifier is reduced and the elution power of the mobile phase is reduced, which results in a stronger retention of the tested compounds [40]. 
T a ble 4

Chromatographic parameters obtained for the azo derivatives in applied modifiers

\begin{tabular}{|c|c|c|c|c|c|c|c|c|}
\hline \multirow{3}{*}{$R$} & \multicolumn{8}{|c|}{ Modifier } \\
\hline & \multicolumn{4}{|c|}{ Methanol } & \multicolumn{4}{|c|}{ Acetonitrile } \\
\hline & $R_{\mathrm{M}}{ }^{0}$ & $m$ & $r$ & $C_{0}$ & $R_{\mathrm{M}^{0}}$ & $m$ & $r$ & $C_{0}$ \\
\hline $\mathrm{H}$ & 0.883 & -1.952 & 0.999 & 0.452 & 0.679 & -1.819 & 0.996 & 0.373 \\
\hline $\mathrm{Cl}$ & 1.138 & -2.296 & 0.998 & 0.496 & 1.109 & -2.375 & 0.993 & 0.467 \\
\hline $\mathrm{Br}$ & 1.217 & -2.398 & 0.996 & 0.508 & 1.175 & -2.452 & 0.995 & 0.479 \\
\hline $\mathrm{F}$ & 0.956 & -2.155 & 0.997 & 0.444 & 0.809 & -2.055 & 0.997 & 0.394 \\
\hline $\mathrm{NO}_{2}$ & 0.522 & -1.510 & 0.995 & 0.346 & 0.356 & -1.415 & 0.998 & 0.252 \\
\hline $\mathrm{OH}$ & 0.701 & -1.795 & 0.993 & 0.391 & 0.495 & -1.589 & 0.996 & 0.312 \\
\hline $\mathrm{COOH}$ & 0.306 & -1.103 & 0.997 & 0.277 & 0.160 & -1.156 & 0.992 & 0.138 \\
\hline $\mathrm{COCH}_{3}$ & 0.414 & -1.318 & 0.996 & 0.314 & 0.287 & -1.295 & 0.995 & 0.222 \\
\hline $\mathrm{CH}_{3}$ & 1.071 & -2.285 & 0.999 & 0.469 & 1.030 & -2.306 & 0.997 & 0.447 \\
\hline $\mathrm{OCH}_{3}$ & 0.798 & -1.893 & 0.998 & 0.422 & 0.635 & -1.769 & 0.998 & 0.359 \\
\hline
\end{tabular}

The retention of the compound is affected to a greater extent by the influence of the substituent's nature. Nonpolar methyl as well as halogen substituents lead to a stronger retention compared to the basic molecule. Conversely, the presence of a polar substituent results in a lower retention in comparison to an unsubstituted molecule. This retention behavior was shown by derivatives with $\mathrm{NO}_{2}, \mathrm{COOH}$ and $\mathrm{COCH}_{3}$ groups, while a much stronger retention was obtained for derivatives with $\mathrm{OH}$ and $\mathrm{OCH}_{3}$ groups. This was not unexpected because this deviation has been noticed in an earlier study [41]. Namely, these two groups are electron donors (they possess a negative value of the Hammett substituent constant, $\sigma$ ), and this causes the formation of an azotautomer that is more strongly bound to the stationary phase [42]. The Hammett substituent constant describes the electronic effects of a substituent bound to the basic molecule. The values of the Hammett substituent constants, $\sigma$, are given in Table $\mathrm{S} 1$.

Also, it is noticeable that the highest retention was observed for the derivative with $\mathrm{Br}$ as a substituent, and the lowest was for the compound with an $\mathrm{COOH}$ group in both applied modifiers.

From observing Table 4, it can be noticed that the $m$ values change in accordance with changes in the $R_{\mathrm{M}}{ }^{0}$ values. Correlation of the mentioned parameters resulted in a linear dependence, which confirmed the assumption that they depend on the same physico-chemical parameters (Table 5).

Table 5

Equations of $R_{M}{ }^{0}-m$ relationships of the azo derivatives in the modifiers used

\begin{tabular}{lcccc}
\hline \hline Modifier & Equation & $r$ & $\mathrm{sd}$ & $p$ \\
\hline Methanol & $R_{\mathrm{M}}{ }^{0}=-0.512-0.702 m$ & 0.993 & 0.038 & $<1 \cdot 10^{-4}$ \\
Acetonitrile & $R_{\mathrm{M}}{ }^{0}=-0.720-0.764 m$ & 0.999 & 0.019 & $<1 \cdot 10^{-4}$ \\
\hline \hline
\end{tabular}

Additionally, the existence of a linear $R_{\mathrm{M}}{ }^{0}-m$ dependence indicates that the selected azo derivatives can be seen as congeneric [43].

Whether the chromatographically obtained parameters, $R_{\mathrm{M}}{ }^{0}, m$ and $C_{0}$, can be used as alternative lipophilicity measures of the azo compounds was examined by their correlation with the software partition coefficient, $\log P$, obtained by applying linear regression (Table 6).
Values of the basic statistical parameters shown in Table 6 (approximately $r>0.940$, sd < 0.095 and $p<0.05$ ) confirm the validity of the established linear relationships. Chromatographic parameters $R_{\mathrm{M}}{ }^{0}, m$, and $C_{0}$ of the azo derivatives obtained in both modifiers used are in good correlation with all of the calculated $\log P$ values (atomic, fragmental and property-contributed). This indicates their reliable application as lipophilicity measures in the given conditions of experimental work. 
T a ble 6

Statistical parameters of the linear models $R_{M}{ }^{0}-\log P, m-\log P$ and $C_{0}-\log P$ for the azo derivatives

\begin{tabular}{|c|c|c|c|c|c|c|c|c|c|}
\hline \multicolumn{2}{|c|}{ Methanol $^{*}$} & $\mathrm{AClog} P$ & $\mathrm{~A} \log P$ & $\mathrm{~A} \log P_{\mathrm{s}}$ & $\mathrm{M} \log P$ & milog $P$ & kowwin & $\mathrm{X} \log P_{2}$ & $\mathrm{X} \log P_{3}$ \\
\hline \multirow{3}{*}{$R_{\mathrm{M}^{0}}$} & $r$ & 0.982 & 0.989 & 0.959 & 0.941 & 0.974 & 0.973 & 0.996 & 0.984 \\
\hline & $\mathrm{sd}$ & 0.038 & 0.030 & 0.058 & 0.069 & 0.046 & 0.047 & 0.018 & 0.037 \\
\hline & $p$ & $<1 \cdot 10^{-4}$ & $<1 \cdot 10^{-4}$ & $6.32 \cdot 10^{-4}$ & 0.002 & $2.06 \cdot 10^{-4}$ & $2.21 \cdot 10^{-4}$ & $<1 \cdot 10^{-4}$ & $<1 \cdot 10^{-4}$ \\
\hline \multirow{3}{*}{$m$} & $r$ & 0.946 & 0.979 & 0.927 & 0.936 & 0.950 & 0.958 & 0.975 & 0.953 \\
\hline & $\mathrm{sd}$ & 0.082 & 0.052 & 0.095 & 0.089 & 0.080 & 0.073 & 0.056 & 0.077 \\
\hline & $p$ & 0.001 & $1.27 \cdot 10^{-4}$ & 0.003 & 0.002 & 0.001 & $6.88 \cdot 10^{-4}$ & $1.78 \cdot 10^{-4}$ & $8.96 \cdot 10^{-4}$ \\
\hline \multirow{3}{*}{$C_{0}$} & $r$ & 0.976 & 0.958 & 0.948 & 0.933 & 0.966 & 0.955 & 0.978 & 0.977 \\
\hline & sd & 0.010 & 0.013 & 0.014 & 0.016 & 0.011 & 0.013 & 0.009 & 0.009 \\
\hline & $p$ & $1.69 \cdot 10^{-4}$ & $6.99 \cdot 10^{-4}$ & 0.001 & 0.002 & $4.07 \cdot 10^{-4}$ & $8.00 \cdot 10^{-4}$ & $1.27 \cdot 10^{-4}$ & $1.48 \cdot 10^{-4}$ \\
\hline \multicolumn{10}{|c|}{ Acetonitrile $^{*}$} \\
\hline \multirow{3}{*}{$R_{\mathrm{M}^{0}}$} & $r$ & 0.982 & 0.998 & 0.968 & 0.909 & 0.975 & 0.976 & 0.992 & 0.985 \\
\hline & $\mathrm{sd}$ & 0.054 & 0.019 & 0.072 & 0.119 & 0.063 & 0.062 & 0.036 & 0.049 \\
\hline & $p$ & $<1 \cdot 10^{-4}$ & $<1 \cdot 10^{-4}$ & $3.56 \cdot 10^{-4}$ & 0.004 & $1.79 \cdot 10^{-4}$ & $1.70 \cdot 10^{-4}$ & $<1 \cdot 10^{-4}$ & $<1 \cdot 10^{-4}$ \\
\hline \multirow{3}{*}{$m$} & $r$ & 0.966 & 0.993 & 0.952 & 0.922 & 0.968 & 0.971 & 0.986 & 0.974 \\
\hline & $\mathrm{sd}$ & 0.094 & 0.043 & 0.112 & 0.143 & 0.093 & 0.088 & 0.061 & 0.083 \\
\hline & $p$ & $3.87 \cdot 10^{-4}$ & $<1 \cdot 10^{-4}$ & $9.16 \cdot 10^{-4}$ & 0.003 & $3.50 \cdot 10^{-4}$ & $2.71 \cdot 10^{-4}$ & $<1 \cdot 10^{-4}$ & $2.04 \cdot 10^{-4}$ \\
\hline \multirow{3}{*}{$C_{0}$} & $r$ & 0.981 & 0.994 & 0.967 & 0.926 & 0.985 & 0.984 & 0.995 & 0.991 \\
\hline & $\mathrm{sd}$ & 0.013 & 0.007 & 0.017 & 0.026 & 0.012 & 0.012 & 0.007 & 0.009 \\
\hline & $p$ & $<1 \cdot 10^{-4}$ & $<1 \cdot 10^{-4}$ & $3.74 \cdot 10^{-4}$ & 0.003 & $<1 \cdot 10^{-4}$ & $<1 \cdot 10^{-4}$ & $<1 \cdot 10^{-4}$ & $<1 \cdot 10^{-4}$ \\
\hline
\end{tabular}

*Derivatives with $\mathrm{NO}_{2}, \mathrm{COOH}$ and $\mathrm{COCH}_{3}$ are excluded (polar substituents with positive values of Hammet constant)

3.3. Correlation between the alternative measure of lipophilicity and selected pharmacokinetic predictors of the azo derivatives by applying linear regression analysis

Table 7 shows the calculated values of selected pharmacokinetic predictors for the studied compounds.
Since the passage of the compounds through various biological membranes is closely related to its lipophilicity, it was assumed that more lipophilic derivatives would have better permeability. In line with expectations, the compound that most easily passed through the phospholipid bilayer of enterocytes was the most lipophilic derivative ( $\mathrm{Br}$ as substituent). On the contrary, the derivative with an OH group substituent had the lowest value of $P_{\text {eff }}$.

T a b l e 7

Pharmacokinetic predictors of the studied azo compounds

\begin{tabular}{lccccccc}
\hline \hline$R$ & $\begin{array}{c}P_{\text {eff }} \\
\left(\mathrm{cms}^{-1}\right)\end{array}$ & $\begin{array}{c}P P B \\
(\%)\end{array}$ & $\begin{array}{c}B B B \\
(\%)\end{array}$ & $\begin{array}{c}\text { pCornea } \\
\left(\mathrm{nms}^{-1}\right)\end{array}$ & $\begin{array}{c}\text { MDCK } \\
\left(\mathrm{nms}^{-1}\right)\end{array}$ & $\begin{array}{c}\text { logK } \\
\left(\mathrm{cmh}^{-1}\right)\end{array}$ & $\begin{array}{c}\text { Tox herg } \\
\left(\mathrm{pIC}_{50}\right)\end{array}$ \\
\hline $\mathrm{H}$ & 2.020 & 81.126 & 0.075 & 117.415 & 70.065 & -3.458 & 4.697 \\
$\mathrm{Cl}$ & 2.703 & 83.948 & 0.317 & 139.785 & 83.196 & -3.515 & 5.047 \\
$\mathrm{Br}$ & 2.877 & 83.908 & 0.347 & 138.917 & 67.442 & -3.402 & 5.023 \\
$\mathrm{~F}$ & 2.558 & 81.934 & 0.189 & 109.121 & 86.521 & -3.735 & 4.908 \\
$\mathrm{NO}_{2}$ & 2.394 & 85.040 & 0.135 & 22.291 & 45.788 & -3.557 & 4.763 \\
$\mathrm{OH}$ & 1.204 & 78.538 & 0.032 & 60.032 & 33.571 & -4.254 & 4.645 \\
$\mathrm{COOH}$ & 1.410 & 78.493 & 0.149 & 41.604 & 26.806 & -3.819 & 4.413 \\
$\mathrm{COCH}$ & 2.163 & 80.728 & 0.099 & 82.798 & 65.565 & -3.722 & 4.788 \\
$\mathrm{CH}_{3}$ & 2.380 & 83.323 & 0.527 & 124.085 & 68.063 & -3.397 & 4.715 \\
$\mathrm{OCH}_{3}$ & 1.924 & 82.112 & 0.019 & 83.479 & 67.519 & -3.703 & 4.762 \\
\hline \hline
\end{tabular}

Simulation plus: $P_{\text {eff }}-$ human effective permeability in jejunum; MDCK - Madin-Darby canine kidney cell permeability line; pCornea - cornea permeability; ToxhERG - cardiac potassium channel encoded by the humanether-a-go-go gene; PreADMET: $P P B$ - plasma protein binding; $B B B$ - blood-brain barrier permeability; $\log K_{\mathrm{sp}}-$ skin permeability 
The values of the distribution parameter through the blood-brain barrier, $B B B$, indicate that the derivative with a $\mathrm{CH}_{3}$ group had the greatest potential as a neuroactive substance $(B B B>0.4)[44]$.

Based on the value of the permeability coefficient, $\log K_{\mathrm{sp}}$, the best transdermal passage was exhibited by the derivative with a $\mathrm{CH}_{3}$ substituent, and the weakest was the derivative with an $\mathrm{OH}$ group.

In addition, it was noticed that derivatives with a nonpolar group or a halogen substituent could exhibit the highest corneal permeability. This is consistent with studies showing that compounds with a $\log P$ between $2.5-2.9$ have optimum corneal permeability [45].

From observing the MDCK values, it can be noted that all of the examined azo derivatives have permeability $\left(25-500 \mathrm{~nm} \cdot \mathrm{s}^{-1}\right)$. Again, higher permeability was obtained for derivatives with nonpolar and halogen substituents [46].

The azo derivative with the $\mathrm{OH}$ group in unbound form reaches the site of action in the highest amount, while the derivative with the highest binding affinity for plasma proteins was the derivative with the $\mathrm{NO}_{2}$ group.

The hERG $\mathrm{IC}_{50}$ values indicate that the studied derivatives with $\mathrm{Cl}$ and $\mathrm{Br}$ can be considered as hERG channel blockers (hERG $\mathrm{IC}_{50}<10 \mu \mathrm{mol} \cdot \mathrm{l}^{-1}$ ) [38].

In order to check the existence of a dependence between chromatographic parameters determined by TLC and selected pharmacokinetic predictors, linear regression analysis was applied. The results are presented in Table 8.

Table 8

Basic statistical parameters of the linear models' chromatographic parameters - pharmacokinetic predictors for the azo derivatives

\begin{tabular}{|c|c|c|c|c|c|c|c|c|}
\hline \multicolumn{2}{|c|}{ Methanol $^{*}$} & $P_{\text {eff }}$ & $P P B$ & $\overline{B B B}$ & MDCK & pCornea & $\log K_{\mathrm{sp}}$ & Toxherg \\
\hline \multirow{3}{*}{$R_{\mathrm{M}^{0}}$} & $r$ & 0.932 & 0.901 & 0.829 & 0.744 & 0.941 & 0.781 & 0.789 \\
\hline & sd & 0.074 & 0.088 & 0.114 & 0.123 & 0.069 & 0.128 & 0.126 \\
\hline & $p$ & 0.002 & 0.005 & 0.021 & 0.090 & 0.002 & 0.038 & 0.035 \\
\hline \multirow{3}{*}{$m$} & $r$ & 0.929 & 0.885 & 0.881 & - & 0.898 & 0.730 & 0.764 \\
\hline & $\mathrm{sd}$ & 0.094 & 0.118 & 0.120 & - & 0.112 & 0.173 & 0.164 \\
\hline & $p$ & 0.002 & 0.008 & 0.009 & - & 0.005 & 0.062 & 0.046 \\
\hline \multirow{3}{*}{$C_{0}$} & $r$ & 0.918 & 0.901 & 0.739 & - & 0.975 & 0.846 & 0.778 \\
\hline & $\mathrm{sd}$ & 0.018 & 0.019 & 0.030 & - & 0.010 & 0.024 & 0.028 \\
\hline & $p$ & 0.004 & 0.006 & 0.058 & - & $1.93 \cdot 10^{-4}$ & 0.016 & 0.039 \\
\hline \multicolumn{9}{|c|}{ Acetonitrile $^{*}$} \\
\hline \multirow{3}{*}{$R_{\mathrm{M}}^{0}$} & $r$ & 0.908 & 0.912 & 0.865 & - & 0.911 & 0.752 & 0.774 \\
\hline & $\mathrm{sd}$ & 0.120 & 0.117 & 0.143 & - & 0.119 & 0.188 & 0.181 \\
\hline & $p$ & 0.005 & 0.004 & 0.012 & - & 0.004 & 0.051 & 0.041 \\
\hline \multirow{3}{*}{$m$} & $r$ & 0.920 & 0.911 & 0.880 & - & 0.906 & 0.744 & 0.772 \\
\hline & $\mathrm{sd}$ & 0.144 & 0.152 & 0.175 & - & 0.156 & 0.246 & 0.234 \\
\hline & $p$ & 0.003 & 0.004 & 0.009 & - & 0.005 & 0.055 & 0.042 \\
\hline \multirow{3}{*}{$C_{0}$} & $r$ & 0.921 & 0.988 & 0.833 & - & 0.931 & 0.821 & 0.763 \\
\hline & $\mathrm{sd}$ & 0.028 & 0.011 & 0.040 & - & 0.026 & 0.041 & 0.046 \\
\hline & $p$ & 0.009 & $1.98 \cdot 10^{-4}$ & 0.040 & - & 0.007 & 0.045 & 0.077 \\
\hline
\end{tabular}

*Derivatives with $\mathrm{NO}_{2}, \mathrm{COOH}$ and $\mathrm{COCH}_{3}$ are excluded.

Results presented in Table 8 confirm that the linear regression analysis gave, on average, satisfactory correlations between the chromatographic parameters and the selected pharmacokinetic predictors. Significant dependence between chromatographic parameters and MDCK values were not obtained. This could be explained by the fact that MDCK permeability not only depends on passive diffusion (which depends strongly on the compound's lipophilicity), but it is also regulated by $\mathrm{P}$ glycoprotein cell influx and efflux [47].
3.4. Correlation between the alternative measure of lipophilicity and the selected toxicity parameters of azo derivatives by applying linear regression analysis

In Table 9 are presented the software values of the effective concentration, $\mathrm{EC}_{50}, \mathrm{mg} \cdot \mathrm{kg}^{-1}$ as a measure of the acute toxicity of the tested compounds for the following test organisms: Algae, Daphnia, Medaka and Minnow (Table 9). 
Table 9

Computational $E C_{50}$ values for the studied azo derivatives on the selected test organisms

\begin{tabular}{lcccc}
\hline \hline$R$ & Algae at & Daphnia at & Medaka at & Minnow at \\
\hline $\mathrm{H}$ & 0.0489 & 0.0615 & 0.0075 & 0.0068 \\
$\mathrm{Cl}$ & 0.0247 & 0.0308 & 0.0021 & 0.0020 \\
$\mathrm{Br}$ & 0.0217 & 0.0251 & 0.0015 & 0.0016 \\
$\mathrm{~F}$ & 0.0384 & 0.0544 & 0.0059 & 0.0033 \\
$\mathrm{NO}_{2}$ & 0.0450 & 0.0533 & 0.0060 & 0.0045 \\
$\mathrm{OH}$ & 0.0389 & 0.0668 & 0.0091 & 0.0071 \\
$\mathrm{COOH}$ & 0.0352 & 0.0639 & 0.0087 & 0.0074 \\
$\mathrm{COCH}$ & 0.0382 & 0.0659 & 0.0092 & 0.0091 \\
$\mathrm{CH}_{3}$ & 0.0266 & 0.0371 & 0.0028 & 0.0024 \\
$\mathrm{OCH}_{3}$ & 0.0366 & 0.0611 & 0.0076 & 0.0071 \\
\hline \hline
\end{tabular}

It can be noted that the derivative with a $\mathrm{Br}$ substituent is the most toxic among all of the examined azo dyes, while all of the tested derivatives are most toxic to the Minnow species.

The relationship between the experimentally determined lipophilicity (chromatographic parame- ters, $R_{\mathrm{M}}{ }^{0}, m$ and $C_{0}$ ) of the studied compounds and the values of their parameters of toxicity $\left(\mathrm{EC}_{50}\right)$ for the different test organisms was evaluated by applying linear regression. The correlation matrix of the established dependencies is presented in Table 10.

Table 10

Basic statistical parameters of the linear models $R_{M}{ }^{0}-E C_{50}, m-E C_{50}$, and $C_{0}-E C_{50}$ for tested azo derivatives

\begin{tabular}{|c|c|c|c|c|c|}
\hline \multicolumn{2}{|c|}{ Methanol $^{*}$} & Algae & Daphnia & Medaka & Minnow \\
\hline \multirow{3}{*}{$R_{\mathrm{M}^{0}}$} & $r$ & 0.781 & 0.970 & 0.980 & 0.940 \\
\hline & sd & 0.127 & 0.050 & 0.040 & 0.070 \\
\hline & $p$ & 0.038 & $2.93 \cdot 10^{-4}$ & $1.04 \cdot 10^{-4}$ & 0.002 \\
\hline \multirow{3}{*}{$m$} & $r$ & 0.804 & 0.958 & 0.978 & 0.979 \\
\hline & sd & 0.151 & 0.073 & 0.052 & 0.052 \\
\hline & $p$ & 0.029 & $6.79 \cdot 10^{-4}$ & $1.32 \cdot 10^{-4}$ & $1.25 \cdot 10^{-4}$ \\
\hline \multirow{3}{*}{$C_{0}$} & $r$ & 0.687 & 0.929 & 0.937 & 0.853 \\
\hline & sd & 0.032 & 0.016 & 0.016 & 0.023 \\
\hline & $p$ & 0.088 & 0.002 & 0.002 & 0.014 \\
\hline \multicolumn{6}{|c|}{ Acetonitrile $^{*}$} \\
\hline \multirow{3}{*}{$R_{\mathrm{M}^{0}}$} & $r$ & 0.842 & 0.988 & 0.997 & 0.952 \\
\hline & sd & 0.154 & 0.045 & 0.022 & 0.087 \\
\hline & $p$ & 0.018 & $<1 \cdot 10^{-4}$ & $<1 \cdot 10^{-4}$ & $9.38 \cdot 10^{-4}$ \\
\hline \multirow{3}{*}{$m$} & $r$ & 0.832 & 0.977 & 0.994 & 0.969 \\
\hline & sd & 0.204 & 0.079 & 0.042 & 0.091 \\
\hline & $p$ & 0.020 & $1.57 \cdot 10^{-4}$ & $<1 \cdot 10^{-4}$ & $3.25 \cdot 10^{-4}$ \\
\hline \multirow{3}{*}{$C_{0}$} & $r$ & 0.805 & 0.975 & 0.990 & 0.930 \\
\hline & sd & 0.040 & 0.016 & 0.010 & 0.025 \\
\hline & $p$ & 0.029 & $1.88 \cdot 10^{-4}$ & $<1 \cdot 10^{-4}$ & 0.002 \\
\hline
\end{tabular}

*Derivatives with $\mathrm{NO}_{2}, \mathrm{COOH}$ and $\mathrm{COCH}_{3}$ are excluded.

The values of all the statistical parameters indicate that the established mathematical models are satisfactory. Thus, the dependence between chromatographic parameters and software obtained 
$\mathrm{EC}_{50}$ values suggests the possibility of using the parameters for predicting the toxicity of tested azo compounds.

\subsection{Study of the azo derivatives 'biological activity parameters using multivariate analysis}

In modern research, multivariate analysis represents an indispensable tool because it enables the classification of a large amount of data from different origins as well as the identification and proper exclusionof those that are redundant [48, 49]. In order to achieve a more comprehensive in silico study of potentially biologically active azo derivatives, two multivariate methods were applied (CA and PCA).

\subsubsection{Results of cluster analysis}

A dendrogram of the studied parameters of biological activity is shown in Figure 1, while Figure 2 shows the dendrogram of the tested derivatives.

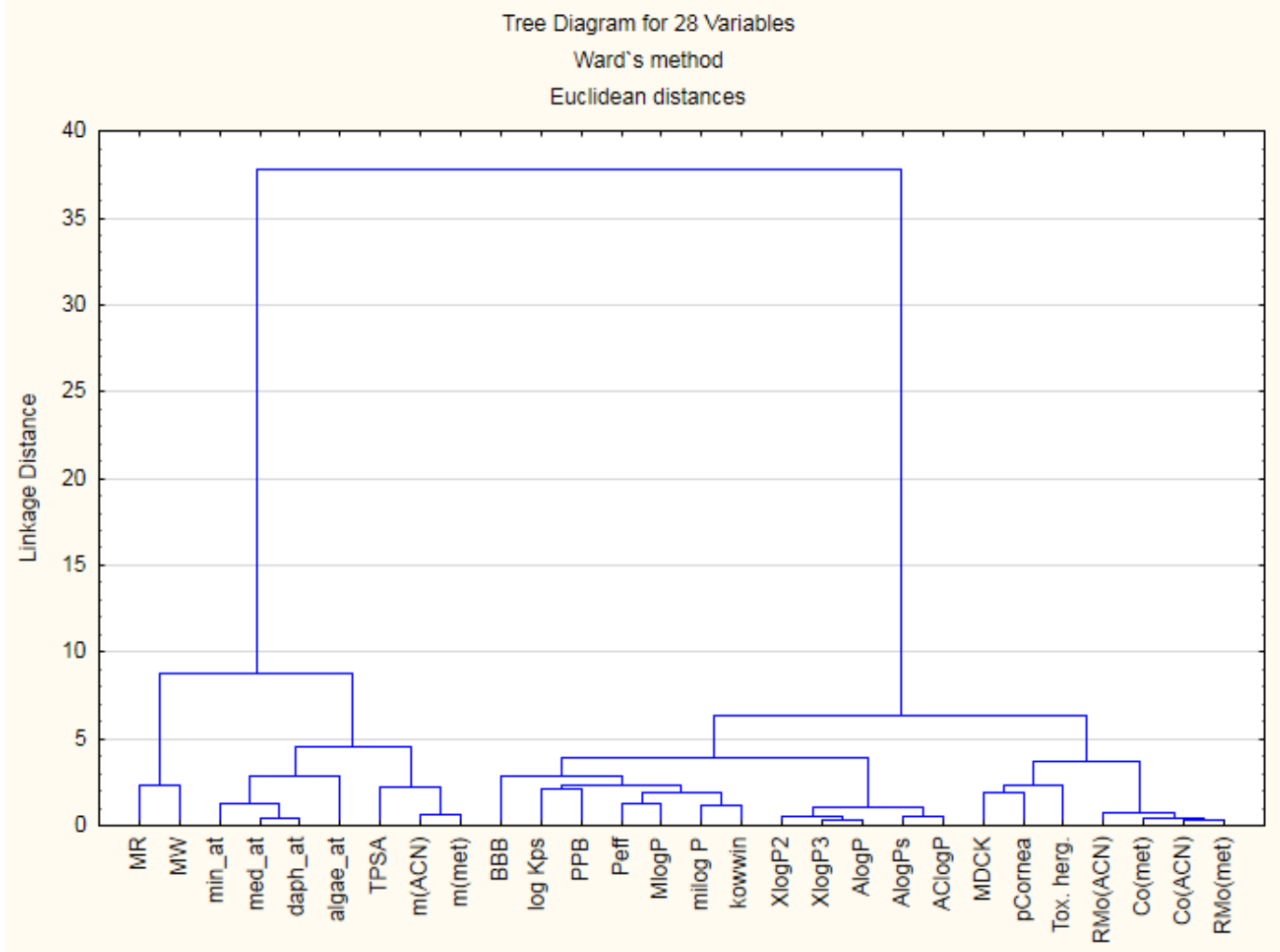

Fig. 1. Dendrogram of the examined biological activity parameters

Figure1 shows that the CA grouped the studied parameters of biological activity into two clearly defined clusters. The first cluster includes the chromatographic parameters, $m$, determined in both of the modifiers used, the toxicity parameters, and drug-likeness descriptors. The second cluster contains pharmacokinetic predictors, mathematically determined parameters of lipophilicity, and other chromatographic parameters obtained in both modifiers. This distribution of the examined parameters of biological activity indicates a greater similarity between the chromatographic parameter $m$ and the toxicity parameters as well as a greater closeness of the chromatographic parameters $\left(R_{\mathrm{M}}{ }^{0}\right.$ and $C_{0}$ ) with the software obtained values of the lipophilicity $(\log P)$ and pharmacokinetic predictors.

Within the cluster formed, the separation of parameters into sub-clusters can be observed. As expected, MR and MW form one cluster, and a second includes parameters of toxicity, while the chromatographic parameters $m$ with TPSA (otherwise conditioned by this descriptor) form the third subgroup.

Three sub-clusters are also noticeable in the second cluster. The first sub-cluster predominantly includes pharmacokinetic predictors, the second $\log P$ values (atom-based extra separated), and the third chromatographic parameters $\left(R_{\mathrm{M}}{ }^{0}\right.$ and $\left.C_{0}\right)$. 


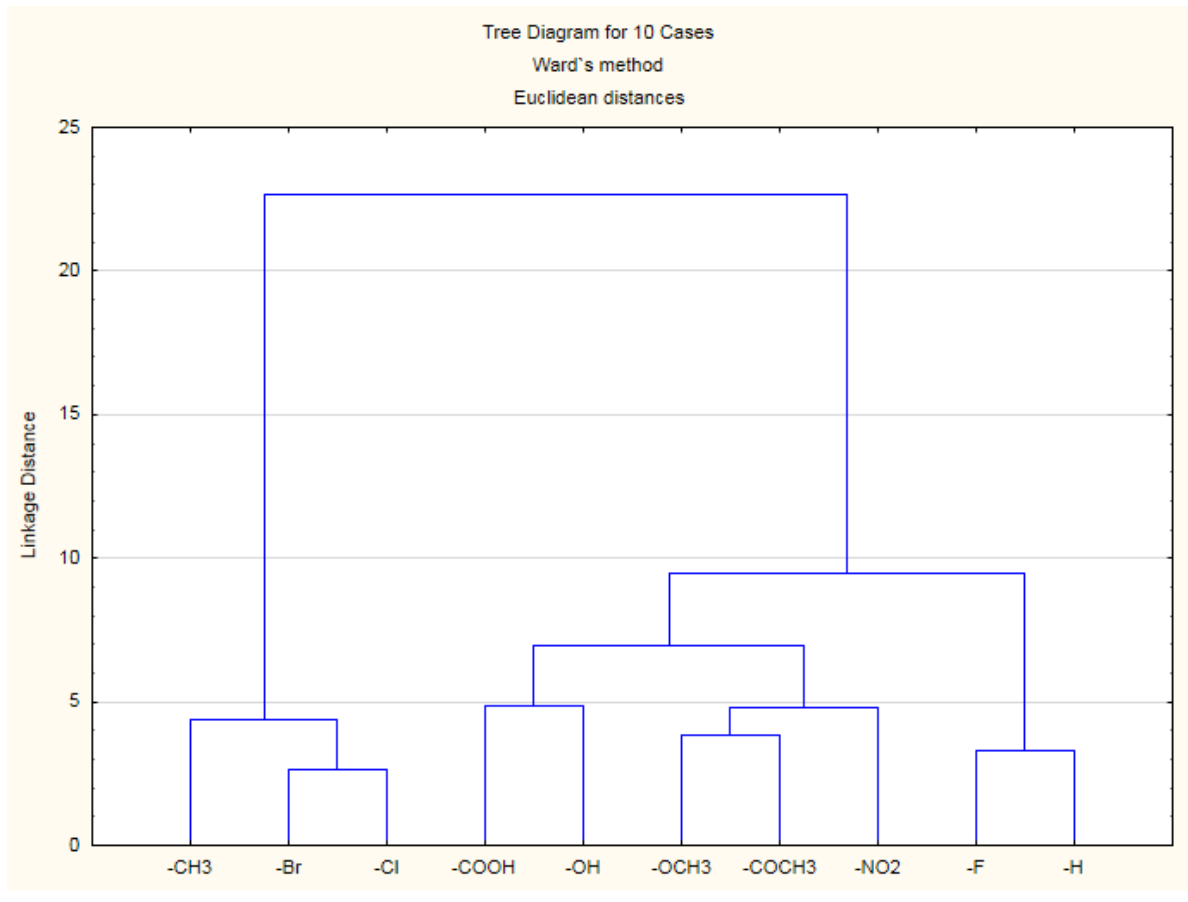

Fig. 2. Dendrogram of the studied azo derivatives

The CA placed the examined azo derivatives into two groups (Fig. 2). The first cluster includes azo derivatives with nonpolar and halogen substituents $\left(\mathrm{CH}_{3}, \mathrm{Br}\right.$ and $\left.\mathrm{Cl}\right)$, except the one with $\mathrm{F}$ as a substituent. Compounds with a polar substituent and the unsubstituted molecule form the other cluster. It is assumed that the difference in size and polarizability of fluorine could be the reason for the separation of this derivative from other halogenated derivatives.

This grouping of the studied azo compounds indicates that their potential biological activity is mostly conditioned by the chemical nature of the presented substituent.

\subsubsection{Results of principal component analysis}

By decomposing the original data matrix to loading vectors and score vectors, PCA enables the elimination of excessive information as well as a significant reduction in the volume of analyzed data. The newly obtained principal components, $\mathrm{PC}$, represent the linear dependence of the original variables. Only those newly formed components whose sum exceeds $80 \%$ are considered to be valid for further analysis.

Figure S1 shows that the three principal components describe about $89 \%$ of the total variables.

The partition of the examined parameters of the biological activity of the studied derivativesis shown in Figure 3 (loading plot).
It can be noticed that the first principal component (PC1) classifies the studied parameters in two clearly defined groups. The first group (negative PC1) includes the chromatographic parameter $m$, toxicity parameters and drug-likeness descriptors, while the second group (positive PC1) consists of the chromatographic parameters $\left(R_{\mathrm{M}}{ }^{0}\right.$ and $C_{0}$ ), pharmacokinetic parameters and mathematically determined parameters of lipophilicity $(\log P)$. Based on this division, as well as in the case of CA, the similarity among the studied parameters of biological activity is confirmed.

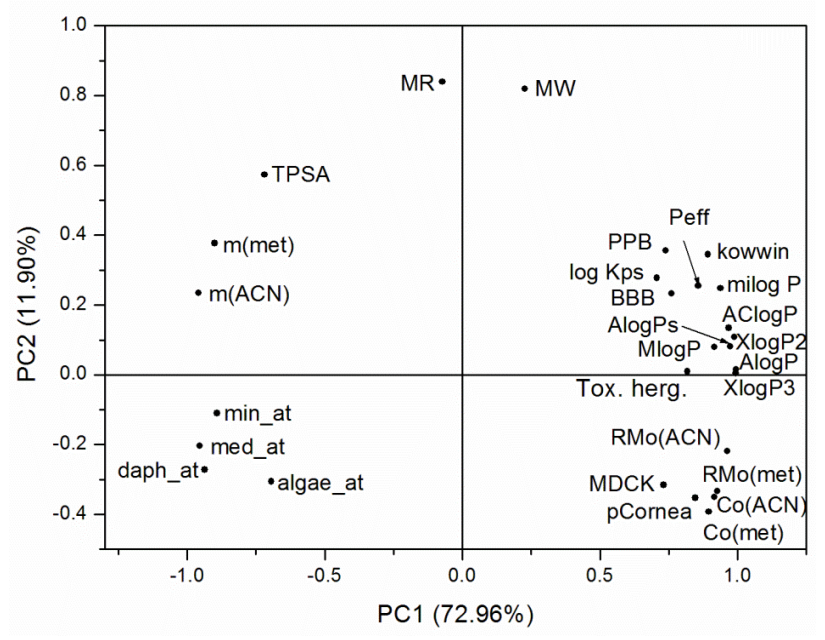

Fig. 3. Eigenvalues of correlation matrix for the studied compounds 
No less significant, the second principal component further organizes the studied parameters. Namely, based on the PC2 value, within the negative PC1, the chromatographic parameter, $m$, is separated from the parameters of toxicity. Also, within the negative PC1, the software parameters of lipophilicity $(\log P)$ and pharmacokinetic parameters are separated from the chromatographic parameters, $R_{\mathrm{M}}{ }^{0}$ and $C_{0}$.
This partition not only shows PCA's ability to detect similarities among the analyzed bioactivity parameters but also the fine dissimilarities incurred as result of different ways of determination.

Figure 4 shows a grouping of the studied derivatives performed by applying PCA to variables, (score plot). It is evident that the first two principal components achieve a good classification of the tested compounds based on the substituent properties.

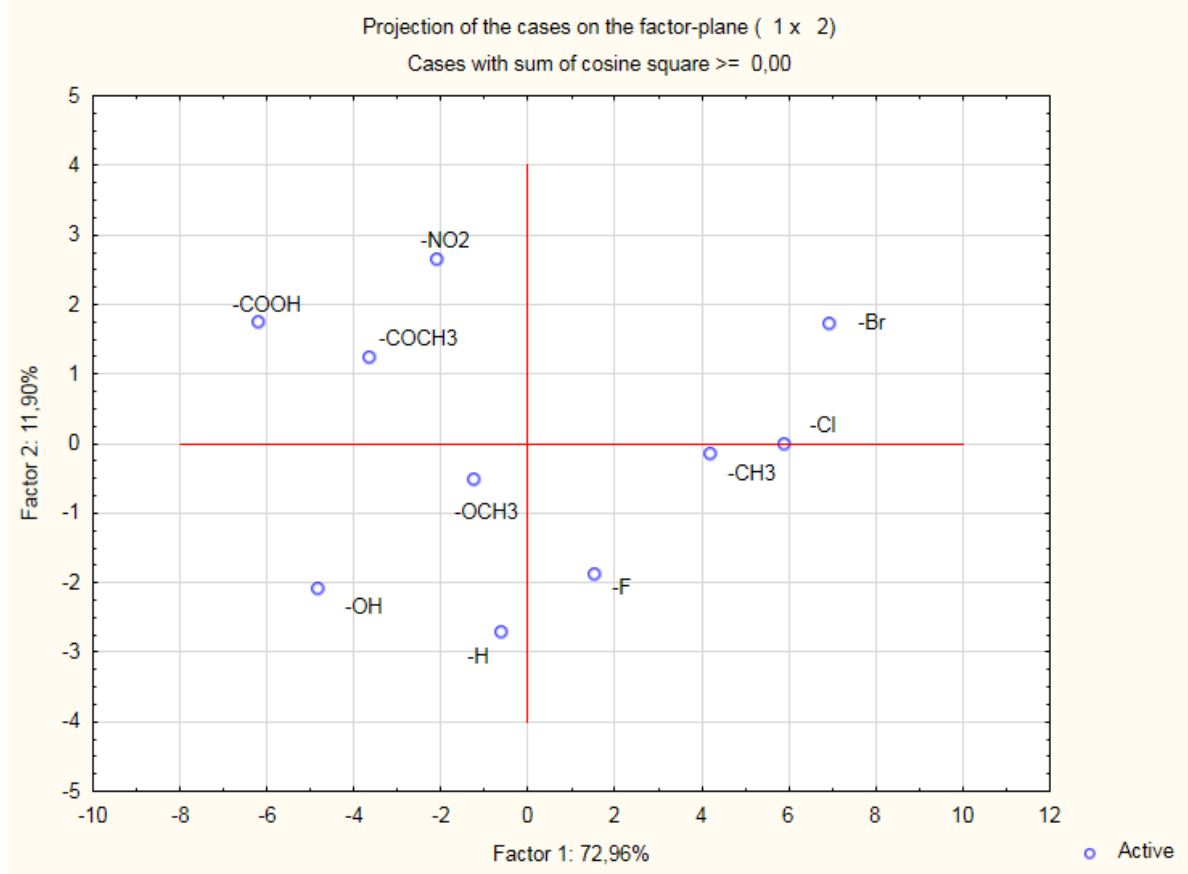

Fig. 4. Loading plot as a result of PC1 versus PC2

The first principal component (PC1) divides the derivatives based on the polarity of the substituent presented in the molecule. The results obtained are similar to the results obtained by the Cluster analysis.

The first group whose $\mathrm{PC} 1$ is negative consists of derivatives with polar substituents $\left(\mathrm{NO}_{2}\right.$, $\mathrm{OH}, \mathrm{COOH}, \mathrm{COCH}_{3}$ and $\mathrm{OCH}_{3}$ ), while the second group with positive $\mathrm{PC} 1$ includes derivatives with non-polar and halogen substituents $(\mathrm{F}, \mathrm{Cl}, \mathrm{Br}$ and $\mathrm{CH}_{3}$ ).

It was assumed that PCA as well as CA clearly separated the investigated compounds based on polarity of the substituent, so the values obtained for PC1 were compared with the Hansch parameter $(\pi)$ using the linear regression method. The Hansch parameter represents the contribution of a particular substituent to the lipophilicity of the molecule. Table S2 gives the values of the Hansch parameter for substituents presented in the analyzed compounds.
The relationship between the values of PC1 and the Hansch parameter is shown in Figure 5.

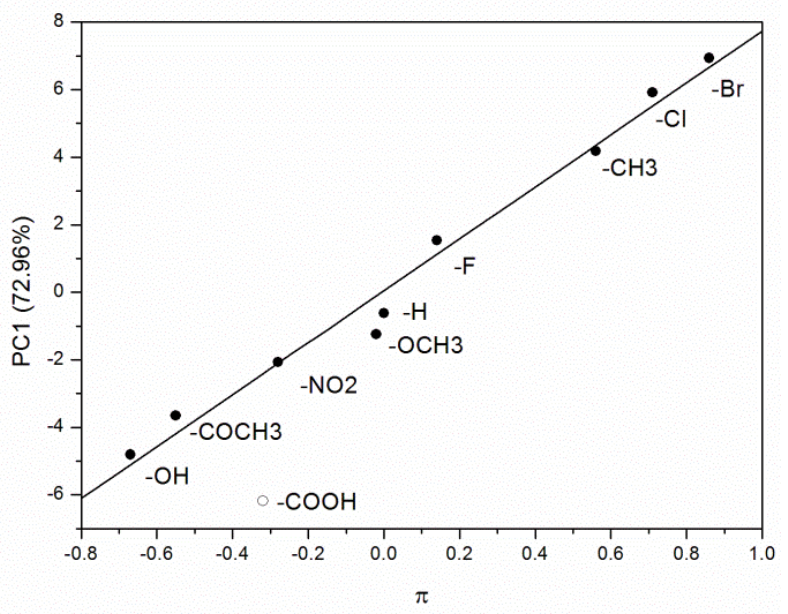

Fig. 5. Relationship between the values of PC1 and the Hansch parameter 
The obtained PC1- $\pi$ linear dependence is described by the following equation:

$$
\begin{aligned}
& \mathrm{PC} 1=0.0454+7.695 \pi, \quad r=0.991 \\
& \mathrm{sd}=0.604 \quad p<1 \cdot 10^{-4}
\end{aligned}
$$

The high value of the correlation coefficient indicates that the polarity of the substituent presented in the molecule has a high impact on the studied properties of the azo derivatives.

Also, the distribution based on PC2 values is noticeable. It is considered that this partitioning is based on the electronic effects of the substituent attached to the molecule. Compounds with negative PC2 values contain substituents that have the ability to donate electrons and further increase reactivity, except for $\mathrm{F}$. These substituents $(\mathrm{OH}$, $\mathrm{OCH}_{3}, \mathrm{~F}$ and $\mathrm{CH}_{3}$ ) favor further substitution in the ortho and para position. Compounds with positive PC2 have deactivating substituents, and they favor further substitution in meta $\left(\mathrm{NO}_{2}, \mathrm{COOH}, \mathrm{COCH}_{3}\right)$ or ortho- and para- positions $(\mathrm{Cl}$ and $\mathrm{Br})$.

The quantitative dependence of the substituent electronic effects on the properties of the azo derivatives was checked by the change of the PC2 value in the function of the Hammett substituent constant, $\sigma$. Unfortunately, no significant correlation was obtained.

\section{CONCLUSION}

In order to obtain information about the bioactive profile of the studied azo derivatives, it was found that they fulfill Lipinski, Ghose and Veber drug-likeness rules. As an alternative measure of lipophilicity, the chromatographic parameters $\left(R_{\mathrm{M}}{ }^{0}\right.$, $m$ and $C_{0}$ ) of the tested azo derivatives were determined by thin layer chromatography on reverse phases (RPTLC C18/ UV254s). It was found that the chromatographic behavior of the tested derivatives is caused by the nature of the presented substituent and to a lesser extent by the nature of the applied modifier. Based on the software-derived lipophilicity parameters $(\log P)$, pharmacokinetic predictors, and ecotoxicity parameters, it was concluded that derivatives with nonpolar or halogen substituents show the best permeation through different biological membranes. Also, none of the derivatives exhibited cardiotoxicity, and for the selected test organisms, the most toxic was the most lipophilic derivative ( $\mathrm{Br}$ as substituent).

The relationship between chromatographic parameters, standard measures of lipophilicity, pharmacokinetic predictors and the toxicity parameters of potentially bioactive azo derivatives was examined by linear regression and two multivariate methods (CA and PCA). Thereby, good linear relationships were obtained for each applied system. The results of multivariate methods show the great resemblance of the chromatographic parameters, $R_{\mathrm{M}}{ }^{0}$ and $C_{0}$ obtained in both modifiers used with standard measures of lipophilicity and pharmacokinetic predictors. On the other hand, the chromatographic parameter $m$, obtained in the same conditions, exhibits better agreement with the druglikeness and toxicity parameters.

In addition, it was concluded that the polarity of a substituent present in the azo molecule influences the values of the bioactivity parameters more than its electronic effect.

Acknowledgement. The authors acknowledge financial support of the Ministry of Education, Science and Technological Development of the Republic of Serbia (Grant No. 451-03-68/2020-14/ 200125). The authors are grateful to the team of Simulations Plus for providing a free trial version.

\section{REFERENCES}

[1] E. J. R. Almeida, C. R. Corso, Decolorization and removal of toxicity of textile azo dyes using fungal biomass pelletized, Int. J. Environ. Sci. Technol., 16, 1319-1328 (2019). DOI: https://doi.org/10.1007/s13762-018-1728-5

[2] B. J. Brüschweiler, S. Küng, D. Bürgi, L. Muralt, E. Nyfeler, Identification of non-regulated aromatic amines of toxicological concern which can be cleaved from azo dyes used in clothing textiles, Regul. Toxicol. Pharmacol., 69, 263-272 (2014).

DOI: https://doi.org/10.1016/j.yrtph.2017.06.012

[3] T. R. Waghmode, M. B. Kurade, R. T. Sapkal, C. H. Bhosale, B. H. Jeon, S. P. Govindwar, Sequential photocatalysis and biological treatment for the enhanced degradation of the persistent azodye methyl red, J. Hazard. Mater., 371, 115-122 (2019).

DOI: https://doi.org/10.1016/j.jhazmat.2019.03.004

[4] M. Hernández-Zamora, F. Martínez-Jerónimo, Congo red dye diversely affects organisms of different trophic levels: a comparative study with microalgae, cladocerans, and zebrafish embryos, Environ. Sci. Pollut. Res., 26, 11743-11755 (2019).

DOI: https://doi.org/10.1007/s11356-019-04589-1

[5] B. J. Brüschweiler, C. Merlot, Azo dyes in clothing textiles can be cleaved into a series of mutagenic aromatic amines which are not regulated yet, Regul. Toxicol. Pharmacol., 88, 214-226 (2017). DOI: https://doi.org/10.1016/j.yrtph.2017.06.012

[6] V. K. Balakrishnan, S. Shirin, A. M. Aman, S. R. de Solla, J. Mathieu-Denoncourt, V. S. Langlois, Genotoxic and carcinogenic products arising from reductive transformations of the azo dye, Disperse Yellow 7, Chemosphere, 146, 206-215 (2016). DOI: https://doi.org/10.1016/j.chemosphere.2015.11.119

[7] M. M. Hashem, Y. M. Abd-Elhakim, K. Abo-EL-Sooud, M. M. E. Eleiwa, Embryotoxic and teratogenic effects of tartrazine in rats, Toxicol. Res., 35, 75-81 (2019). DOI: https://doi.org/10.5487/TR.2019.35.1.075 
[8] P. Rani, V. K. Srivastava, A. Kumar, Synthesis and antiinflammatory activity of heterocyclic indole derivatives, Eur. J. Med. Chem., 39, 449-452 (2004).

DOI: https://doi.org/10.1016/j.ejmech.2003.11.002

[9] M. Gaber, Y. S. El-Sayed, K. Y. El-Baradie, R. M. Fahmy, Complex formation, thermal behavior and stability competition between $\mathrm{Cu}$ (II) ion and $\mathrm{Cu}^{0}$ nanoparticles with some new azodyes. Antioxidant and in vitro cytotoxic activity, Eur. J. Med. Chem., 107, 359-370 (2013). DOI: https://doi.org/10.1016/j.saa.2013.01.039

[10] N. N. Ayare, S. H. Ramugade, N. Sekar, Photostable coumarin containing azo dyes with multifunctional property, Dyes Pigm., 163, 692-699 (2019). DOI: https://doi.org/10.1016/j.dyepig.2018.12.050

[11] V. Dimova, N. Perišić-Janjić, Qsar study by 1,2,4triazoles using several physicochemical descriptors, Maced. J. Chem. Chem. Eng., 28, 79-89 (2009). DOI: http://dx.doi.org/10.20450/mjcce.2009.223

[12] X. Xu, F. Luan, H. Liu, J. Cheng, X. Zhang, Prediction of the maximum absorption wavelength of azobenzene dyes by QSPR tools, Spectrochim. Acta, Part A, 83, 353-361 (2011). DOI: https://doi.org/10.1016/j.saa.2011.08.046

[13] D. Vaněrková, P. Jandera, J. Hrabica, Behaviour of sulphonated azodyes in ion-pairing reversed-phase highperformance liquid chromatography, J. Chromatogr. A 1143, 112-120 (2007).

DOI: https://doi.org/10.1016/j.chroma.2006.12.075

[14] S. Manganelli, E. Benfenati, A. Manganaro, S. Kulkarni, T. S. Barton-Maclaren, M. Honma, New quantitative structure-activity relationship models improve predictability of ames mutagenicity for aromatic AZO compounds, Toxicol. Sci., 153, 316-326 (2016). DOI: https://doi.org/10.1093/toxsci/kfw125

[15] P. S. Jogi, J. Meshram, J. Sheikh, T. Ben Hadda, Synthesis, biopharmaceutical characterization, and antimicrobial study of novel azo dyes of 7-hydroxy-4methylcoumarin, Med. Chem. Res., 22, 4202-4210 (2013). DOI: https://doi.org/10.1007/s00044-012-0421-3

[16] I. Azad, M. Nasibullah, T. Khan, F. Hassan, Y. Akhter, Exploring the novel heterocyclic derivatives as lead molecules for design and development of potent anticancer agents, J. Mol. Graphics Modell., 81, 211-228 (2018). DOI: https://doi.org/10.1016/j.jmgm.2018.02.013

[17] S. Boudergua, M. Alloui, S. Belaidi, M. M. Al Mogren, U. A. A. Ellatif Ibrahim, M. Hochlaf, QSAR modeling and drug-likeness screening for antioxidant activity of benzofuran derivatives, J. Mol. Struct., 1189, 307-314 (2019). DOI: https://doi.org/10.1016/j.molstruc.2019.04.004

[18] M. J. Waring, Lipophilicity in drug discovery, Expert Opin. Drug Discovery, 5, 235-248 (2010). DOI: https://doi.org/10.1517/17460441003605098

[19] C. M. Hosey, L. Z. Benet, Predicting the extent of metabolism using in vitro permeability rate measurements and in silico permeability rate predictions, Mol. Pharmaceutics, 12, 1456-1466 (2015). DOI: https://doi.org/10.1021/mp500783g

[20] N. P. Milošević, V. B. Dimova, N. U. Perišić-Janjić, RP TLC data in correlation studies with in silico pharmacokinetic properties of benzimidazole and benztriazole derivatives, Eur. J. Pharm. Sci., 49, 10-17 (2013). DOI: https://doi.org/10.1016/j.ejps.2013.01.018
[21] S. Šegan, J. Penjišević, V. Šukalović, D. Andrić, D. Milojković-Opsenica, S. Kostić-Rajačić, Investigation of lipophilicity and pharmacokinetic properties of 2(methoxy)phenylpiperazine dopamine D2 ligands, $J$. Chromatogr. B: Anal. Technol. Biomed. Life Sci., 1124, 146-153 (2019). DOI: https://doi.org/10.1016/j.jchromb.2019.06.006

[22] A. H. Rageh, N. N. Atia, H. M. Abdel-Rahman, Lipophilicity estimation of statins as a decisive physicochemical parameter for their hepato-selectivity using reversed-phase thin layer chromatography, J. Pharm. Biomed. Anal., 142, 7-14 (2017). DOI: https://doi.org/10.1016/j.jpba.2017.04.037

[23] A. Olivares-Morales, H. Lennernäs, L. Aarons, A. Rostami-Hodjegan, Translating Human Effective Jejunal Intestinal Permeability to Surface-Dependent Intrinsic Permeability: A Pragmatic Method for a More Mechanistic Prediction of Regional Oral Drug Absorption, AAPS J. 17, 1177-1192 (2015).

DOI: https://doi.org/10.1208/s12248-015-9758-0

[24] M. J. Cho, D. P. Thompson, C. T. Cramer, T. J. Vidmar, J. F. Scieszka, The Madin Darby Canine Kidney (MDCK) Epithelial Cell Monolayer as a Model Cellular Transport Barrier, Pharm. Res., 6, 71-77 (1989). DOI: https://doi.org/10.1023/A:1015807904558

[25] P. Ballabh, A. Braun, M. Nedergaard, The blood-brain barrier: An overview: Structure, regulation and clinical implications, Neurobiol. Dis., 16, 1-13 (2004). DOI: https://doi.org/10.1016/j.nbd.2003.12.016

[26] C. Toma, D. Gadaleta, A. Roncaglioni, A. Toropov, A. Toropova, M. Marzo, E. Benfenati, QSAR Development for Plasma Protein Binding: Influence of the Ionization State, Pharm. Res., 36, Article number 28 (2019). DOI: https://doi.org/10.1007/s11095-018-2561-8

[27] C. P. Chen, C. C. Chen, C. W. Huang, Y. C. Chang, Evaluating molecular properties involved in transport of small molecules in stratum corneum: A quantitative structure-activity relationship for skin permeability, Molecules, 23, Article number 911 (2018). DOI: https://doi.org/10.3390/molecules23040911

[28] G. A. R. Oliveira, R. N. Ducas, G. C. Teixeira, A. C. Batista, D. P. Oliveira, M. C. Valadares, Short Time Exposure (STE) test in conjunction with Bovine Corneal Opacity and Permeability (BCOP) assay including histopathology to evaluate correspondence with the Globally Harmonized System (GHS) eye irritation classification of textile dyes, Toxicol. In Vitro, 29, 1283-1288 (2015). DOI: https://doi.org/10.1016/j.tiv.2015.05.007

[29] H. M. Lee, M. S. Yu, S. R. Kazmi, S. Y. Oh, K. H. Rhee, M. A. Bae, B. H. Lee, D. S. Shin, K. S. Oh, H. Ceong, D. Lee, D. Na, Computational determination of hERG-related cardiotoxicity of drug candidates, $B M C$ Bioinf., 20, Article number 250 (2019). DOI: https://doi.org/10.1186/s12859-019-2814-5

[30] J. Trifunović, V. Borčić, S. Vukmirović, V. Vasović, M. Mikov, Bile acids and their oxo derivatives: environmentally safe materials for drug design and delivery, Drug. Chem Toxicol., 40, 397-405 (2017). DOI: https://doi.org/10.1080/01480545.2016.1244680

[31] B. M. Matijević, Đ. Đ. Vaštag, S. L. Apostolov, F. Assaleh, A. D. Marinković, D. Ž. Mijin, Solvatochromism of thiouracil azo dyes, J. Solution Chem., 45, 885-906 (2016). DOI: https://doi.org/10.1007/s10953-016-0482-x 
[32] E. C. Bate-Smith, R. G. Westall, Chromatographic behaviour and chemical structure. I. Some naturally occurring phenolic substances, Biochim. Biophys. Acta., 4, 427-440 (1950).

DOI: https://doi.org/10.1016/0006-3002(50)90049-7

[33] E. Soczewiński, C. A. Wachtmeister, The relation between the composition of certain ternary two-phase solvent systems and $R_{\mathrm{M}}$ values, J. Chromatogr., A 7, 311320 (1962).

DOI: https://doi.org/10.1016/S0021-9673(01)86422-0

[34] G. L. Biagi, A. M. Barbaro, A.; Sapone, M. Recanatini, Determination of lipophilicity by means of reversedphase thin-layer chromatography. I. Basic aspects and relationship between slope and intercept of TLC equations, J. Chromatogr. A, 662, 341-361 (1994). DOI: https://doi.org/10.1016/0021-9673(94)80521-0

[35] M. L. Bieganowska, A. Doraczynska-Szopa, A. Petruczynik, The retention behaviour of some sulphonamides on different TLC plates. 2. Comparison of the selectivity of the systems and quantitative determination of hydrophobicity parameters, J. Planar Chromatogr.-Mod. TLC, 8, 122-128 (1995).

[36] http://www.vcclab.org (accessed in September 2013)

[37] https://www.molinspiration.com/(accessed in March 2019)

[38] www.simulation-plus.com (accessed in September 2013)

[39] https://preadmet.bmdrc.kr/ (accessed in June 2017)

[40] D. Dabić, M. Natić, Z. Džambaski, R. Marković, D. Milojković-Opsenica, Z. Tešić, Quantitative structureretention relationship of new N-substituted 2-alkylidene4-oxothiazolidines, J. Sep. Sci., 34, 2397-2404 (2011). DOI: https://doi.org/10.1002/jssc.201100266

[41] G. Vastag, S. Apostolov, B. Matijević, Assaleh, F. QSRR approach in examining selected azo dyes, J. Liq. Chromatogr. Relat. Technol., 39, 674-681 (2016). DOI: https://doi.org/10.1080/10826076.2016.1230748
[42] D. Z. Mijin, G. S. Ušćumlić, N. V. Valentić, A. D. Marinković, Synthesis of azo pyridone dyes [Sinteza arilazo piridonskih boja], Hem. Ind., 65, 517-532 (2011). DOI: https://doi.org/10.2298/HEMIND110428037M

[43] T. Cserháti, Lipophilicity determination of some monoamine oxidase inhibitors by reversed-phase thin-layer chromatography, The effect of $\mathrm{pH}$, J. Liq. Chromatogr. 16, 1805-1817 (1993). DOI: https://doi.org/10.1080/10826079308021688

[44] M. Lobell, L. Molnár, G. M. Keserü, Recent advances in the prediction of blood-brain partitioning from molecular structure, J. Pharm. Sci., 92, 360-370 (2003). DOI: https://doi.org/10.1002/jps.10282

[45] M. Malhotra, D. K. Majumdar, Permeation through cornea, Indian J. Exp. Biol., 39, 11-24 (2001). DOI: http://hdl.handle.net/123456789/23624

[46] J. D. Irvine, L. Takahashi, K. Lockhart, J. Cheong, J. W. Tolan, H. E. Selick, J. R. Grove, MDCK (Madin-Darby canine kidney) cells: A tool for membrane permeability screening, J. Pharm. Sci., 88, 28-33(1999). DOI: https://doi.org/10.1021/js9803205

[47] S. Kovačević, M. K. Banjac, S. Podunavac-Kuzmanović, N. Milošević, J. Ćurčić, J. Vulić, V. Šeregelj, N. Banjac, G. Ušćumlić, Chromatographic and computational screening of an isotropic lipophilicity and pharmacokinetics of newly synthesized 1-aryl-3-ethyl-3-methylsuccinimides, Comput. Biol. Chem., 84, Article number 107161 (2020). DOI: https://doi.org/10.1016/j.compbiolchem.2019.107161

[48] I. Ionut, B. Tiperciuc, O. Oniga, Lipophilicity evaluation of some N1-arylidene-thiosemicarbazones and 1,3,4thiadiazolines with antimicrobial activity, J. Chromatogr. Sci., 55, 411-416 (2017).

DOI: https://doi.org/10.1093/chromsci/bmw195

[49] G. Vastag, S. Apostolov, D. Mijin, L. Grbović, B. Kaurinović, Chemometric study of chromatographic and computational bioactivity parameters of diphenylacetamides, J. Chemom., 33, e3091 (2019). DOI: https://doi.org/10.1002/cem.3091 